\title{
Study of Development of Rural Entrepreneurship in Modern Russia
}

\author{
Z.I. Kalugina \\ Professor of Sociology, Institute of Economics and Industrial Engineering, Russian academy of Sciences, \\ Siberian Branch, Novosibirsk State University, Novosibirsk
}

\begin{abstract}
The article discusses the trends and prospects of development of the three sectors of rural entrepreneurship: corporate, individual and family, formal and informal; analyze the transformation of household farms; an assessment of efficiency of development of small forms of agricultural production, it is concluded that the major agricultural organizations lost their dominant position.
\end{abstract}

Keywords - agricultural production, farms, households, corporate sector, private sector.

\section{INTRODUCTION}

Market reforms in Soviet Russia were the subject of researches of many domestic and foreign authors. The focus became the adaptation of enterprises and population to the new socio-economic conditions, new forms and models of management, new rules, new norms and values [21-29]. In the course of market reforms of 90-ies was created the institutional framework for the development of rural entrepreneurship. First, was a land reform, reorganization of collective and state farms, removed administrative barriers to the development of private farming, agricultural workers were endowed with property and land share. Thus the rural population got a startup capital for the business. About the extent to which the rural population had benefited, preserved the entrepreneurial spirit of the Russian peasant, not lost if he patterns a calculating master, a trace in his consciousness and behavior left a 70-year experience of the "Communist labor" we will try to analyze through the prism of the development of the dominant structures in the agricultural sector of Russia in 1991-2016.

According to the Civil code of the Russian Federation, "the entrepreneurial self is undertaken at your own risk activities aimed at systematically profit from the use of property, sale of goods, performing works or rendering services by persons registered in this capacity in the prescribed manner". The subject of our consideration is the population activity on production, processing and marketing of agricultural products.

\section{THE DYNAMICS OF THE DOMINANT ECONOMIC STRUCTURES}

On the eve of market reforms in the Russian agricultural sector was dominated by two organizational-legal forms of agricultural production: collective sector and household plots. The collective sector was represented by two types of agricultural enterprises: collective farms based on production cooperation of farmers and collective ownership of the means of production (land, equipment, livestock, seeds etc) and state agricultural enterprises (state farms), based on state ownership of land and other means of production. In the collective sector produced about $70 \%$ of agricultural production.

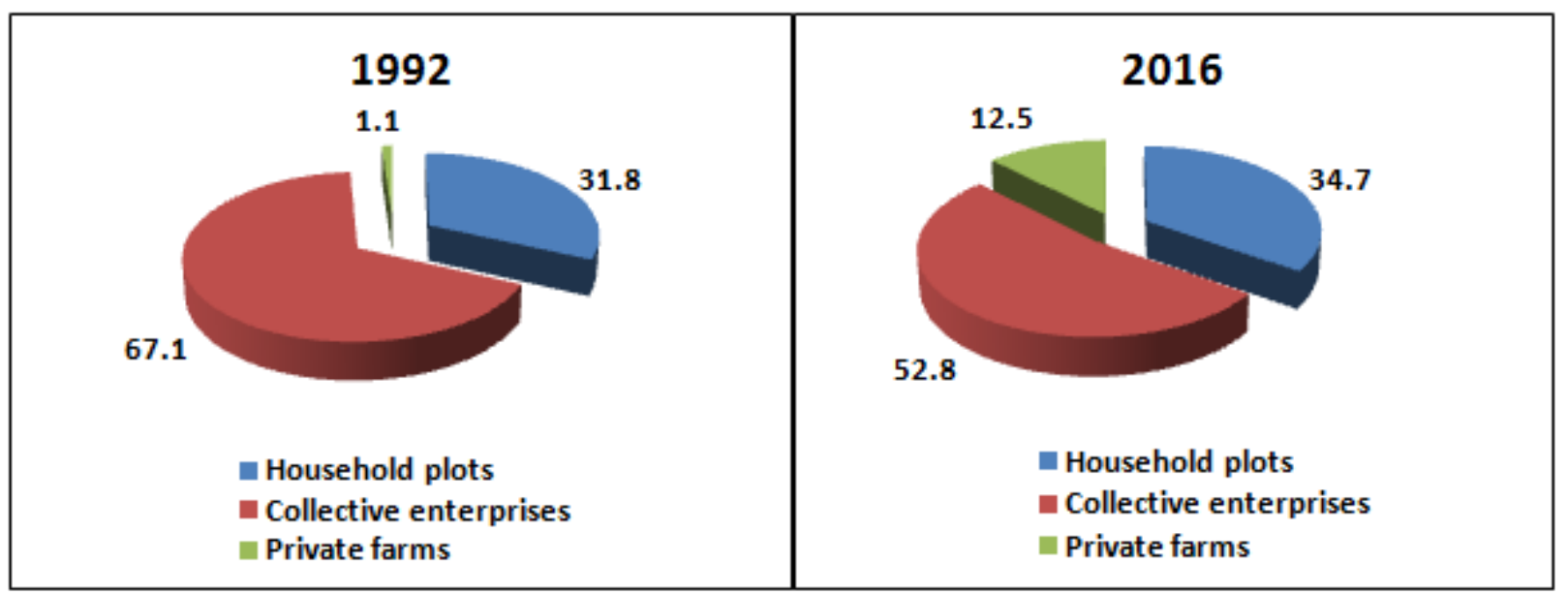

Figure 1. Structure of Agricultural Production in RuSSia BaSed on Market Value of AGRICUltURAL COMMODITIES, 1992 AND 2016, \% .

Source: [1,p.245] 
Since the beginning of market reforms in Russia has passed the quarter of a century. In this period changed the balance of power in the agrarian sector. Statistics indicate that the role of big business in agricultural production contrary to expectations has decreased not so much. In Soviet times the share of agricultural enterprises accounted $67 \%$ of total agricultural production, at the present time $-53 \%$ (Fig.1). Agricultural enterprises dominate the production of grain - $71 \%$, sugar beets $88 \%$, livestock and poultry (slaughter weight) $-76 \%$, eggs $-79 \%$, sunflower seeds $90 \%$. There are also about half the amount of milk and $70 \%$ of meat (slaughter weight) [1, p.246].

One third of agricultural output continues to produce household plots. The share of private farms accounts for only one-tenth part of agricultural production. Individual farm labor was not attractive to the rural population of Russia [1, p. 245].

Typological analysis of the socio-economic development of rural regions has allowed revealing the regional specificity in the structure of production by types of farms [2]. The analysis showed that in the I cluster of regions where agricultural production is developing successfully and it focuses mainly on large collective enterprises. The number of household plots is much lower compared to other regions. Their share in the production of agricultural products varies from $27 \%$ (I cluster) to $36 \%$ (II cluster).

The second group (II cluster) is represented by 10 regions located mostly in the South and in the Central Chernozem zone, and adjacent to large Metropolitan agglomerations (Moscow and Leningrad region). They are characterized by the use of innovative technologies and large scale investment in agriculture. The scale of investment in these regions was twice lower than in Krasnodar Krai, but significantly exceeded their size in all other clusters. This determined the technical and technological modernization of the agricultural sector and ensured higher profitability of animal production and crop production, and yield of grain crops and productivity of animals.

In this group of regions (II cluster), the lowest share of loss-making agricultural organizations: $23,2 \%$ vs $53,6 \%$ in the sixth cluster and $42,1 \%$ - in the fourth cluster. In General, rural areas of this group produce one-third of all agricultural output in the country. In this case the dominant role in the production playing the major agricultural organizations, the share of households account for 36\%, while the share of private farms in this class of regions is 7,5\%. The smallest number of peasant (farmer) farms noted in the fourth cluster of rural regions. Basically, it is the regions non-farm profile. Among them degraded areas Nechernozemie and Northern Russia with unfavorable climatic conditions.

Most are filled with third cluster of rural regions of the Central Chernozem region, Volga region, as well as suitable for agriculture of the regions of Western Siberia and the Urals, which produce more than $40 \%$ of agricultural production. The main producers are agricultural organizations and the farming population. Peasant (farmer's) farm produce here for less than $10 \%$ of agricultural production. Households in this group in the rural areas provide about $45 \%$ of agricultural production.

Family forms of agricultural production (households and private farms) are most developed in the fifth and sixth clusters. They are represented by regions became the Eastern border area with low density of population and the Caucasian Republic with limited land resources. The sixth cluster represents the remote North-Eastern and southern regions with predominant development of home and farms. Here, on the one hand, due to the climatic characteristics of the regions are limited opportunities for conducting of large-scale agricultural production (Sakha-Yakutia, Magadan and Sakhalin regions), and on the other, the development of production was constrained due to the prevailing socio-political circumstances (Chechen Republic and Dagestan) [2].

Thus, we can say that over the last 15-20 years the process of market transformations in agricultural production decreased the role of large agricultural enterprises and significantly increased the role of family forms of agricultural production. Informal family forms of agricultural production occurred in the 2000 years, rather in spite of, not because of agrarian reform. A significant growth in the products grown in the farms of the population, shows not about success but rather about failures carried out agrarian reforms. The informal agrarian economy is a form of adaptation and survival of the rural population in the process of reforming of agrarian relations.

Many collective farms in the result of hasty, ill-considered and total conversions were destroyed. The rural society was not ready to return to individual farming. Lost experience of individual and family agricultural production on a large scale returns slowly and as if involuntarily. However, poverty forced the rural population to return to your past experience. In terms of production of agricultural products of family farms began to compete with large collective agricultural enterprises, and in some regions ahead of them (V and VI clusters). 
In recent years the structure of agricultural production by categories of farms suggests that imposed on top of economic and institutional innovations in agriculture have been based on historical experience, traditions and preferences of the peasants. As a result of ongoing agricultural policy did not always produce the desired results, and the dominant economic structures, contrary to the expectations of the reformers, developed for their specific trajectories. Try to understand the anatomy of their development.

\section{MIMICRY OF THE HOUSEHOLd PLOTS}

In Soviet times household plots acted important economic and social functions. First of all, it is an economic function: family agricultural production raising the standard of living of the rural population by increasing mobile revenues, improve material consumption, including food resource use of labour of all family members, rational land use, including a small marginal plots.

A social function of private farming is primarily in the labor education of the younger generation, the formation of professional qualities and skills of effective and economical farming. The recreational role of the personal subsidiary farming - it is the consumption of high-quality natural food and strengthen the physical health of family members

Subsistence nature of family agricultural production was due to the fact that the main occupation of the family members, who have reached working age, was work on the collective farms, in social institutions or in other fields. Of the able-bodied young people was busy studying in school or vocational training. Work in the family economy was for all family members and voluntary utility (relative to main occupation) in nature and served as an additional source of family income.

Household plots based on state or cooperative ownership of land and private ownership of productive livestock, buildings, means of mechanization and tools have made a significant contribution to the solution of the food problem of the country. However, in the absence in Soviet times, the free market needed small-sized agricultural machinery, weak development and an extremely limited set of services provided to rural population, the existence of personal subsidiary farming was impossible without the active support of the agricultural enterprises.

The symbiosis of private plots and collective farms has been and remains in the focus of sociologists and economists [3-6].

Deterrent to the development of private farms in the Soviet period was the high employment rate of rural population into collective farms (sovkhozes and kolkhozes). Work in his household was for the most part unoccupied by the population, as well as employees during off hours. If given the opportunity, employees have taken and part of the working day. Currently the situation has changed significantly. Large agricultural organizations with the participation of private capital are not condoned today to employees. In private enterprises introduced a system of fines for employees who violate labor discipline. The services provided by the collective or private farms are paid.

In modern conditions the role of personal part-time farm has changed significantly. For many rural residents it has become the main employment-generating a substantial share of the incomes of rural families. Private farming was transformed, in the terminology of O. Fadeeva, "family-consumer way of life" in the "family business system". If the dominant goal of economic activity in the first case, is survival at the expense of own production and receipt of income in kind as compensation for missing income, in the second - stable money income [6. C.35].

Under Russian law, private agriculture (household plots) is a form of non-entrepreneurial activities in the production and processing of agricultural products, carried out by personal labour of a citizen and members of his family in order to meet personal needs on the land, granted or acquired for private farming. The land use of the farms may consist of the household plots and in field plots.

In government statistics, instead of the term "households", the term "farm population", which include private and individual farms of citizens in rural and urban areas, and households with land plots at vegetable, gardening and dacha non-profit associations. The functioning of households is based on the initiative of the informal agricultural activities of citizens, selffunded, self-organization and labour relations based on kinship, neighboring, or personal interactions.

Today, households are the main producers of potatoes, vegetables, one third of the total production of milk (table. 1). This suggests that households are in the modern conditions a significant source not only of natural but also of cash income of the rural population. This is especially true when you consider that wages for agricultural workers remains among the lowest in the economy. Average monthly salary in agriculture was in $2000-985$ rubles per month, $2005-3646,2010-10668,2015-$ 
19721,20016 - 21445 rubles, which corresponded to $53 \%$ of the average wage in the economy as a whole. In 2005 , this ratio was $39 \%$ [1, p.125]. But the main motive of private farming is the satisfaction of the needs of rural families in natural foods.

The expansion of production in the informal sector of the economy due to a significant reduction in the number of employed in formal sector agriculture. In the period from 2005 to 2016 the number of employed in agriculture decreased by 1.2 million. In 2016, it amounted to 6,286 million, or 9.2 percent of the population employed in the economy [1, p. 93]. For comparison, in developed countries such as the UK, Germany, France, the United States population, employed in agricultural labor is approximately two times lower and ranges from 1.5 to $4-5 \%$ of the population employed in the economy.

TABLE 1

AGRICULTURAL PRODUCTION BY CATEGORIES OF FARMS \% OF TOTAL

\begin{tabular}{|c|c|c|c|c|}
\hline & 1992 & 2000 & 2010 & 2016 \\
\hline \multicolumn{5}{|c|}{ Agriculture enterprises } \\
\hline Grain & 97,4 & 90,8 & 77,1 & 71,4 \\
\hline Sugar beet & 97,8 & 94,5 & 88,7 & 88,1 \\
\hline Sunflower seeds & 93,0 & 84,3 & 73,0 & 68,7 \\
\hline Potatoes & 21,2 & 7,5 & 10,5 & 13,6 \\
\hline Vegetables & 44,5 & 22,9 & 17,1 & 18,9 \\
\hline Fruits and berries & 49,0 & 15,7 & 15,0 & 23,7 \\
\hline $\begin{array}{l}\text { Livestock and poultry (slaughter } \\
\text { weight) }\end{array}$ & 64,0 & 47,3 & 44,9 & 49,0 \\
\hline Milk & 68,1 & 89,4 & 92,3 & 49 \\
\hline Eggs & 73,9 & 12,3 & 18,3 & 20,3 \\
\hline \multicolumn{5}{|c|}{ Household plots } \\
\hline Grain & 0,5 & 0,8 & 1,0 & 0,9 \\
\hline Sugar beet & 0,2 & 0,6 & 0,4 & 0,2 \\
\hline Sunflower seeds & 1,2 & 1,2 & 0,6 & 0,4 \\
\hline Potatoes & 78,0 & 91,2 & 84,0 & 77,9 \\
\hline Vegetables & 54,7 & 74,7 & 71,5 & 66,5 \\
\hline Fruits and berries & 50,7 & 16,5 & 16,0 & 19,1 \\
\hline $\begin{array}{l}\text { Livestock and poultry (slaughter } \\
\text { weight) }\end{array}$ & 35,3 & 36,7 & 46,7 & 45,5 \\
\hline Milk & 31,4 & 26,1 & 31,2 & 33,9 \\
\hline Eggs & 26,0 & 28,8 & 22,1 & 19,9 \\
\hline \multicolumn{5}{|c|}{ Peasant farming* } \\
\hline Grain & 2,1 & 8,4 & 21,9 & 27,7 \\
\hline Sugar beet & 2,0 & 4,9 & 10,9 & 11,7 \\
\hline Sunflower seeds & 5,8 & 14,5 & 26,4 & 30,9 \\
\hline Potatoes & 0,8 & 1,3 & 5,5 & 8,5 \\
\hline Vegetables & 0,8 & 2,4 & 11,4 & 14,6 \\
\hline Fruits and berries & 0,3 & 0,2 & 2,2 & 1,9 \\
\hline $\begin{array}{l}\text { Livestock and poultry (slaughter } \\
\text { weight) }\end{array}$ & 0,7 & 1,8 & 2,9 & 2,9 \\
\hline Milk & 0,5 & 1,8 & 4,7 & 7,0 \\
\hline Eggs & 0,1 & 04 & 0,8 & 1,0 \\
\hline
\end{tabular}

*) Including individual entrepreneurs Source: [1, p.246].

Given the very limited choice of jobs in rural areas, we can safely say about the formation of a "reserve army of labor." Part released from agricultural production of labor resources engaged in seasonal work, and other work in shifts in the next cities and regions of the country [7]. Part of the unemployed rural residents provides a variety of services to the population, freelance at the place of residence [8, pp. 207-229; 9, pp. 265-295]. But the bulk of the rural unemployed find application in their farms. According to the state statistics for 2014, agricultural productions in their farms were occupied 647 thousand for the rural unemployed. In conjunction with unemployed working-age population, they account for about $30 \%$ of the labour force used in manufacturing of agricultural products (table. 2). 


\section{TABLE 2}

THE POPULATION IN AGE 15-72 YEARS OCCUPIED BY MANUFACTURING PRODUCTS AGRICULTURE, FISHING, HUNTING AND GATHERING FOR THEIR OWN THE USE, AGE AND STATUS OF PARTICIPATION IN THE LABOUR FORCE IN 2014, THOUSAND PEOPLE

\begin{tabular}{|c|c|c|c|c|c|}
\hline & $\begin{array}{c}\text { Just including } \\
\text { from it }\end{array}$ & labour power & busy & unemployed & $\begin{array}{c}\text { persons not in the } \\
\text { labor force }\end{array}$ \\
\hline Just including at age, years: & 13640 & 8779 & 8132 & 647 & 4861 \\
\hline $15-24$ & 1222 & 526 & 419 & 107 & 696 \\
\hline $25-34$ & 2050 & 1737 & 1585 & 152 & 313 \\
\hline $35-44$ & 2413 & 2162 & 2024 & 139 & 251 \\
\hline $45-54$ & 3273 & 2812 & 2643 & 169 & 462 \\
\hline $55-64$ & 3447 & 1442 & 1365 & 77 & 2005 \\
\hline $65-72$ & 1234 & 100 & 96 & 4 & 1133 \\
\hline Working age & 9605 & 7808 & 7206 & 602 & 1796 \\
\hline
\end{tabular}

Source: [10, p. 96].

The employed population is $60 \%$ of the labor force involved in family agricultural production, the unemployed $-5 \%$, of working age outside the workforce - $13 \%$. More than $22 \%$ of those employed in the informal sector of agricultural production is of working age, i.e. it is the elderly and teenagers. The structure of the labour resources employed in the informal sector of agricultural production, reflects the effective use of the labor potential of the household.

The duration of the working week in the informal sector of agricultural production lasts from 15 to 40 hours a week. According to statistics, over $60 \%$ of population were employed on his farm less than 15 hours a week, around $25 \%$ from 15 to 24 hours, and every tenth - from 25 to 39 hours per week and only 3 per cent had a full 40-hour work week [Calculated source: 10, p. 95].

Thus, in the period of market transformations of the farming population lost its purely a utility character and became an important sector of agricultural production. Our eyes have been mimicry of private farming, which was transformed into a large informal sector of agricultural production. The consolidation of small archaic households as one of the leading sectors of the agrarian economy was the paradoxical result of the market reforms in the agricultural sector of the country. However, it is not, in our view, a consequence of the free choice of the peasants. For the majority of the rural population, the conduct of household plots is the only way to survive in difficult conditions of market reforms.

In the Federal law "About Households " from July 7, 2003, this category of farms was recognized as a form of nonentrepreneurial activity for the production of agricultural products that are subject to the same measures of state support to large and medium-sized agricultural enterprises. Thanks to these measures we managed to avoid a significant reduction in the volume of production in farms of the population, deprived of the support of the reorganized collective farms.

\section{THE DEVELOPMENT OF PRIVATE PEASANT FARMS}

In the process of economic reforms of 90 -ies had established the institutional basis and legal framework for development of all types of entrepreneurial activities in rural areas and the formation of mixed agrarian economy. After the entry into force of the RF law "On peasant (farmer) economy" and the Law of the Russian Federation 1995 "On state support of small entrepreneurship in Russia," the Russian peasants have a real opportunity to rule your own business and become independent economic entities.

Federal law "On peasant (farmer) economy" (entered into force on 11.06.2003, as amended 01.03.2015) defines a peasant (farmer) economy as an Association of citizens who have common property and jointly engaged in the production, processing, storage, transportation and realization of agricultural products. Household Plots areas a business entity without legal entity formation [11].

However, the farming sector, as we anticipated in the 90-ies [12], did not become the dominant mode in agricultural production of Russia. The state of public consciousness, the duration of formation of market relations, socio-demographic situation in the village, a dispersed settlement system, poor development of communication system have become a limiting factor for the wide spread of farms and turning them into the dominant form of agricultural production. Nevertheless, and in Russia after 70 years of collective labour in the farms were willing to work independently and become effective owners of their farms. 
Only in 2000-e years the acreage in farms increased threefold, from 6.5 million hectares to 19.7 million hectares in 2014 , the farm sector has occupied a steady position in the production of grains and oilseeds, as well as in the production of vegetables and sugar beet. The number of cattle in the farming sector during this period increased $4.2 \%$, including cows -5.5 times. Almost 10 times increase in the number of sheep and goats, 4.6 times the number of poultry. Continuously remains small, the number of pigs. However, meat production in the farming sector in the observed period of time tripled. Milk production has increased by about as much.

Currently, in the peasant (farm) produces one-quarter of the total volume of grain, about one-third of wool and sunflower seed, one-tenth of vegetables and sugar beet, (tab. 1). Today the crop is in farms $3 / 4$ of the production, and livestock $-1 / 4$.

According to the Federal tax service on August 1, 2015, was 3 million 510 thousand individual entrepreneurs and 139600 farms. The number of individual entrepreneurs that ceased operations at his own request, in January - July, 2015 decreased by $22.5 \%$, and farms $-33.5 \%$ [13]

For comparison, in the United States in 1935, there were 6.5 million farms in 2014 to 2.1 million. The Number of people employed in agriculture decreased from $10 \%$ of the population to $2 \%$. Over the last decade, the ratio of the scale of the farms varied in the direction of gradual reduction of small and growth of large farms. Currently in the US, large family farms, constituting $12 \%$ of all farms of the country produced $89 \%$ of US agricultural products in value terms [14].

Positive trends in the agricultural business of Russia, as experts believe, will continue. According to the Association of peasant (farmer) farms and agricultural cooperatives, $38 \%$ of the rural population in Russia would like to create the farm [15]. Besides, as says a Russian proverb, - "there would be no happiness, the misfortune has helped". The introduction of a food embargo against our country and the response of Russia led to the transition to import substitution in many sectors of the economy, including agriculture. Support of agricultural commodity producers of all forms of ownership, although necessary, has given a new impetus in the development of the agricultural complex of the country, including the farming sector.

Limiting factors of development of peasant (farm) in Russia, according to our many years of research, are: insecurity of property rights; weak support from the state; high taxes; the imbalance of agricultural prices, depressed by low solvent demand of the population, and increasing prices for agricultural equipment, fuel and lubricants and other resources; high interest rates; underdeveloped communication and road network in the countryside.

In the long term growth of the farm sector of the agricultural economy will restrain significant growth of the property tax and increase land tax.

Part of the failure of development of the farming sector due to subjective reasons related to the lack of Russian peasants of experience in self-management, a lack of specialized knowledge, unwillingness to work in the conditions of economic and social risk that has developed over the years of Soviet power the specific culture of doing joint work, the feeling of social security in the team. It is no coincidence therefore that sociologists record a certain sorrow of the older generation about the past.

A well-known researcher of the Russian village, Vinogradsky, V. G. suggests the emergence among the peasants of a certain generational sadness, i.e. a kind of yearning for the past, socialist system the peasant world. This memory of the past, according to the author, can play the role of a "healing socio-cultural drugs". Soaked in rural daily life of new generations, it will lead to new Russian peasant worlds [16].

As for the younger generation, I would venture to say that the rural youth is more likely to aspire to the city, in order to get rid of the heavy farm labour from the insecurity of rural life.

\section{PROSPECTS OF DEVELOPMENT OF SMALL FORMS OF AGRICULTURAL PRODUCTION}

Prospects for development of farms and other small forms of agricultural production determined in large part by the State program of development of agriculture and regulation of markets of agricultural products, raw materials and food for 2013 2020 [17].

A separate sub-programme dedicated to the "Support of small forms of managing". Her goal: maintenance and further development of agricultural and non-agricultural activities small farms and improving the quality of life in rural areas. Objectives sub-programme: creating conditions for increasing the number of small business entities; improving the efficiency of use of land from agricultural lands; increase the level of rural incomes. 
The Subprogram will allow by 2020 to create an additional 14 thousand (peasant) farms, which provide jobs for 42,15 thousand annual average of employees; full implementation of the program of creation of livestock farms by 2020 to increase milk production in peasant (farmer) farms on 675 thousand tons; the growth of agricultural products produced by small businesses, amounting to $7.4 \%$.

The subroutine includes four groups of activities:

- $\quad$ "Support of beginning farmers" in the form of granting grants on creation and development of peasant (farmer) farms.

- "Development of family livestock farms on the basis of the peasant (farmer) farms", i.e. construction or modernisation of family farms, the size of the grant issued from the Federal budget and budgets of constituent entities of the Russian Federation may not exceed $60 \%$ of the costs of the peasant (farmer's) economy.

- $\quad$ "State support of lending to small farms" through subsidies from the Federal budget to budgets of subjects of the Russian Federation on compensation of part of expenses for payment of percent on the Bank credits and loans received in agricultural credit consumer cooperatives, peasant (farm) holdings

- $\quad$ "The registration of land property of a peasant (farming)". The purpose of the event - compensation expenses for carrying out of cadastral works concerning the ground areas from the agricultural land. Currently, the average cost of execution of the plot is 1000 rubles for 1 ha. From the Federal budget compensation was provided about 500 RUB per 1 ha, which is about $50 \%$ of the total cost, the remaining funds necessary to conduct cadastral works are provided from the budgets of the constituent entities of the Russian Federation and municipal formations.

\section{TRENDS OF DEVELOPMENT OF AGRICULTURAL ENTERPRISES}

The basis of the corporate sector of the agrarian economy after market reforms amounted to the reorganized collective and state farms that repeatedly changed its legal status on the basis of the incentives from the state had one or another legal form. These were joint stock companies and partnerships of all types, agricultural cooperatives, and vertically integrated agricultural organization, agricultural and agricultural holdings.

The main challenge was adapting to the market, search of reliable partners and markets. Business tried to get rid of excess labor. Suffice it to say that during the period from 1995 to 2013, the number of people employed in agriculture fell by more than 3 million people.

But, despite all the efforts of the agricultural organizations, they failed to overcome the devastating consequences of the market agrarian reform. A significant share of agricultural enterprises remained unprofitable, despite the fact that the share of unprofitable agricultural organizations decreased significantly (Fig. 2)

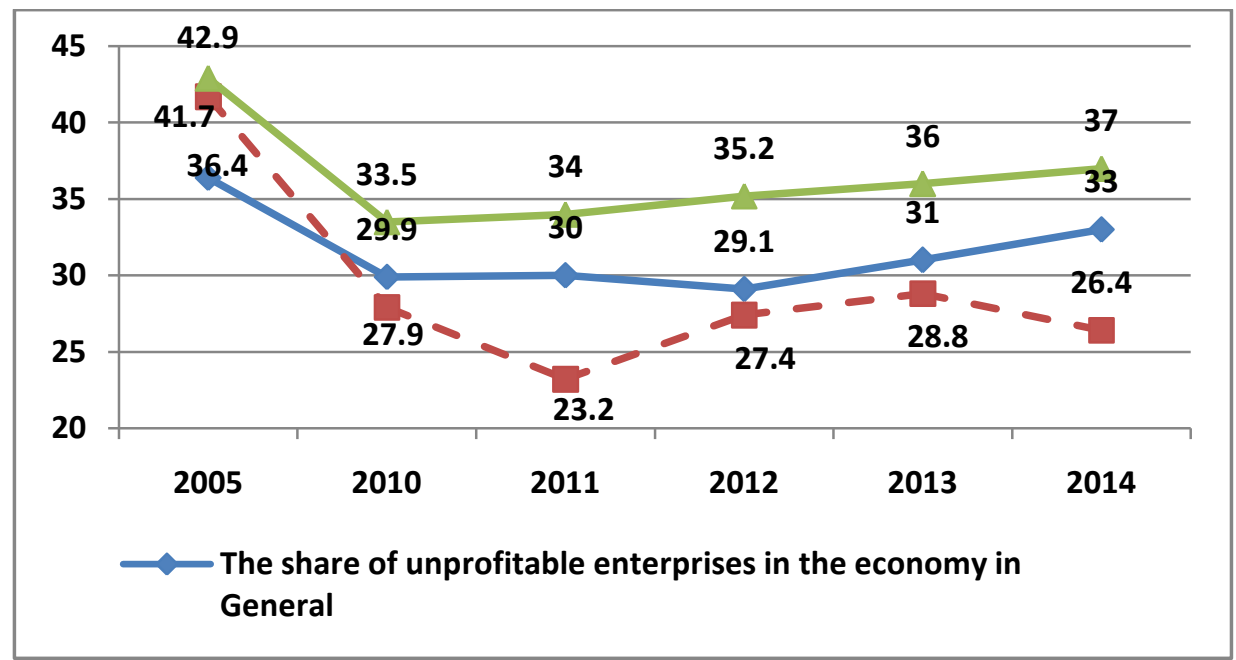

\section{FIGURE 2. THE SHARE OF UNPROFITABLE ORGANIZATIONS AND THE DEGREE OF WEAR OF FIXED ASSETS IN RURAL ECONOMY, \% Source: [18, pp. 44-48].}

One of the reasons for the low efficiency of production in agricultural organizations was low, the scale of investment in fixed capital. Since 2005, their level did not exceed the 2.7-3\% of the total. The coefficient of disposal (liquidation) of fixed assets 
in agriculture was higher compared to all fixed assets in the economy as a whole, and renewal coefficient of fixed assets is lower (tab. 3). As a result, in 2000-ies in agricultural organizations three times decreased the tractors, harvesters, mowers, milking machines and aggregates, five times decreased the number of sugar beet machinery and other equipment [18, p. 64].

TABLE 3

THE COEFFICIENT UPDATE AND DISPOSAL OF FIXED ASSETS (IN COMPARABLE PRICES), INVESTMENT IN FIXED CAPITAL IN AGRICULTURE OF RUSSIA *)

\begin{tabular}{|c|c|c|c|c|c|c|}
\hline & $\mathbf{2 0 0 5}$ & $\mathbf{2 0 1 0}$ & $\mathbf{2 0 1 1}$ & $\mathbf{2 0 1 2}$ & $\mathbf{2 0 1 3}$ & $\mathbf{2 0 1 4} \mathbf{1}^{\mathbf{1}}$ \\
\hline The share of unprofitable farms in the economy as a whole & 3,0 & 3,7 & 4,6 & 4,8 & 4,6 & 4,3 \\
\hline All fixed assets in that number and forestry agriculture & 2,4 & 3,7 & 4,3 & 4,2 & 4,3 & 4,0 \\
\hline $\begin{array}{c}\text { Retirement rate (elimination fixed assets as a percentage of } \\
\text { availability fixed assets at the beginning of the year) }\end{array}$ & 1,1 & 0,8 & 0,8 & 0,7 & 0,7 & 0,7 \\
\hline $\begin{array}{c}\text { All fixed assets in that number agriculture, hunting and } \\
\text { forestry agriculture }\end{array}$ & 4,2 & 2,2 & 2,4 & 2,5 & 2,1 & 2,1 \\
\hline $\begin{array}{c}\text { Investments in fixed capital (in current prices), } \\
\text { billion. }\end{array}$ & 313,8 & 79,1 & 201,8 & 256,9 & 276,3 & 307,1 \\
\hline percentage of total investment & 2,7 & 3,0 & 3,0 & 2,9 & 3,1 & 3,0 \\
\hline
\end{tabular}

*) Without small businesses and investment not observed by direct statistical methods. Source: [18, pp. 60-61].

State support is an integral part of agricultural policy in many countries. An example of effective use of existing resources and technologies is the Netherlands with an area of 41 thousand sq $\mathrm{km}$ (less Moscow region), the agricultural sector employs only $4 \%$ of the working population, produces of agricultural products 55 billion euro per year. This is the second after the United States increased agricultural production. Currently, subsidies in the EU reached 45-50\% of the cost of production of farmers in Japan and Finland - $70 \%$, in Russia - only $3.5 \%$. In the United States in the development of agriculture invested 30\% more money (per unit of production) than in other industries [19].

In the period from 1992 to 2016 the contribution of agricultural enterprises in the production of goods decreased from $67,1 \%$ to $52,8 \%$, respectively. The livestock population in this period decreased from 40.2 to 8.4 million animals, and the livestock of cows from 13.7 to 3.4 million heads. In 2000, agricultural organizations in the production of milk yielded its primacy to households. Positive trends in milk production was observed only in the farming sector (Fig. 3,4).

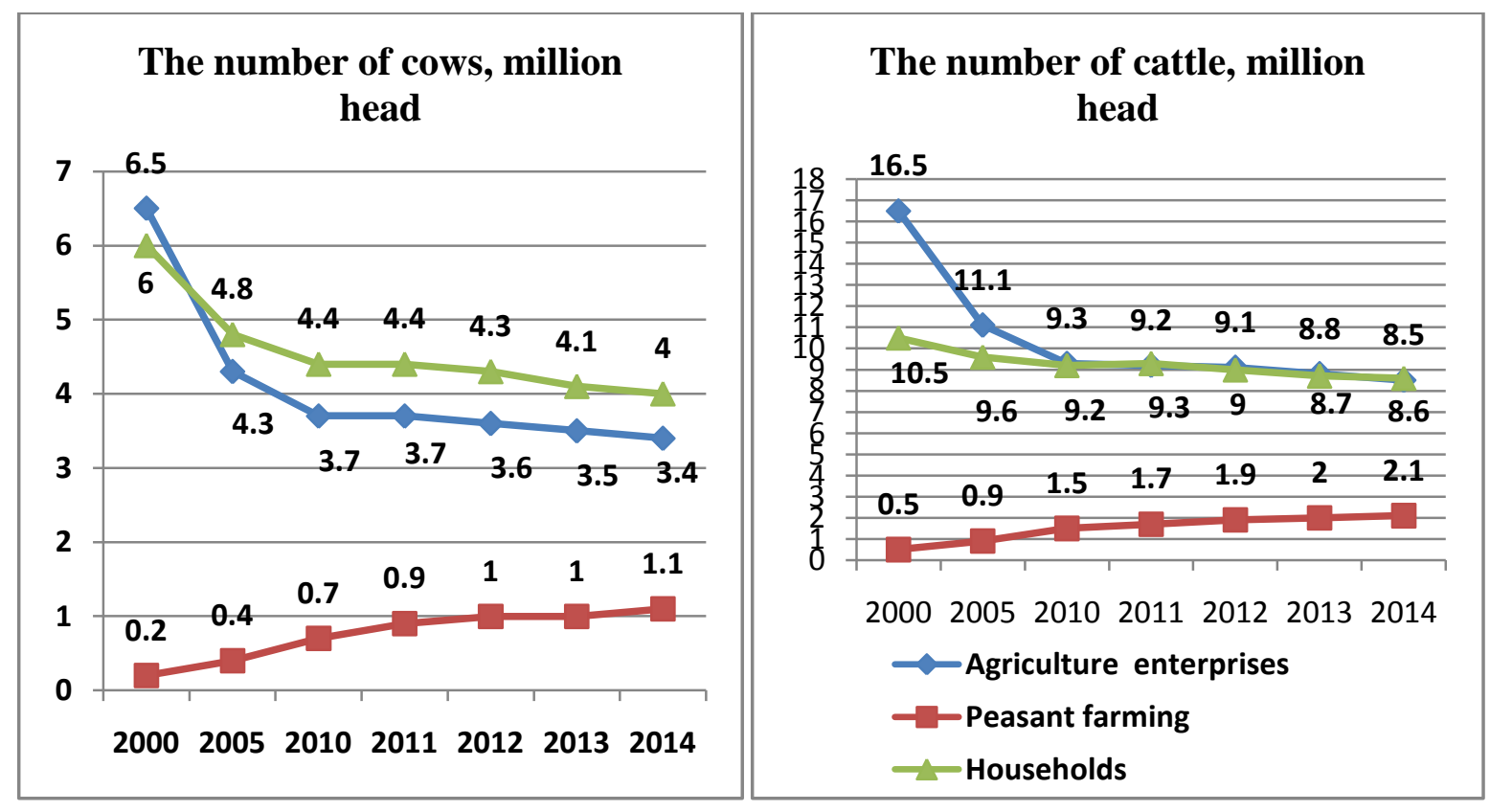

FigURE 3, 4. THE NUMBER OF CATTLE, INCLUDING COWS BY TYPES OF FARMS, MILLION HEAD Source: $[18, p .94]$. 
The acreage in agricultural organizations decreased during the same period, from 74.2 to 55.3 million hectares, including grain crops and leguminous cultures - from 40.7 to 32.2 million ha (Fig.5). But at the same time significantly increased the production of grain: 59, 4 million tons to 77.6 million tons According to experts, Russia could become the largest grain producer in the world. Sugar beet production increased from 13, 3 to 29.9 million tons, and potatoes with 2, 2 million tons to 3.8 million tons [18, p. 55].

The acreage in agricultural organizations decreased during the same period, from 74.2 to 55.3 million hectares, including grain crops and leguminous cultures - from 40.7 to 32.2 million ha (Fig.5).

The coefficient of disposal (liquidation) of fixed assets in agriculture was higher compared to all fixed assets in the economy as a whole, and renewal coefficient of fixed assets is lower (tab. 3). As a result, in 2000-ies in agricultural organizations three times decreased the tractors, harvesters, mowers, milking machines and aggregates, five times decreased the number of sugar beet machinery and other equipment [18, p. 64].

The conversion of agricultural enterprises appeared in 2000-ies in increasing numbers of pigs by 1.8 times, the doubling of poultry, which increased meat production $3.7 \%$, including pork - by 5.5 times, poultry meat - by 7.5 times. Eggs production has increased by 8.4 billion pieces. Milk production has decreased by 0.9 million tons.

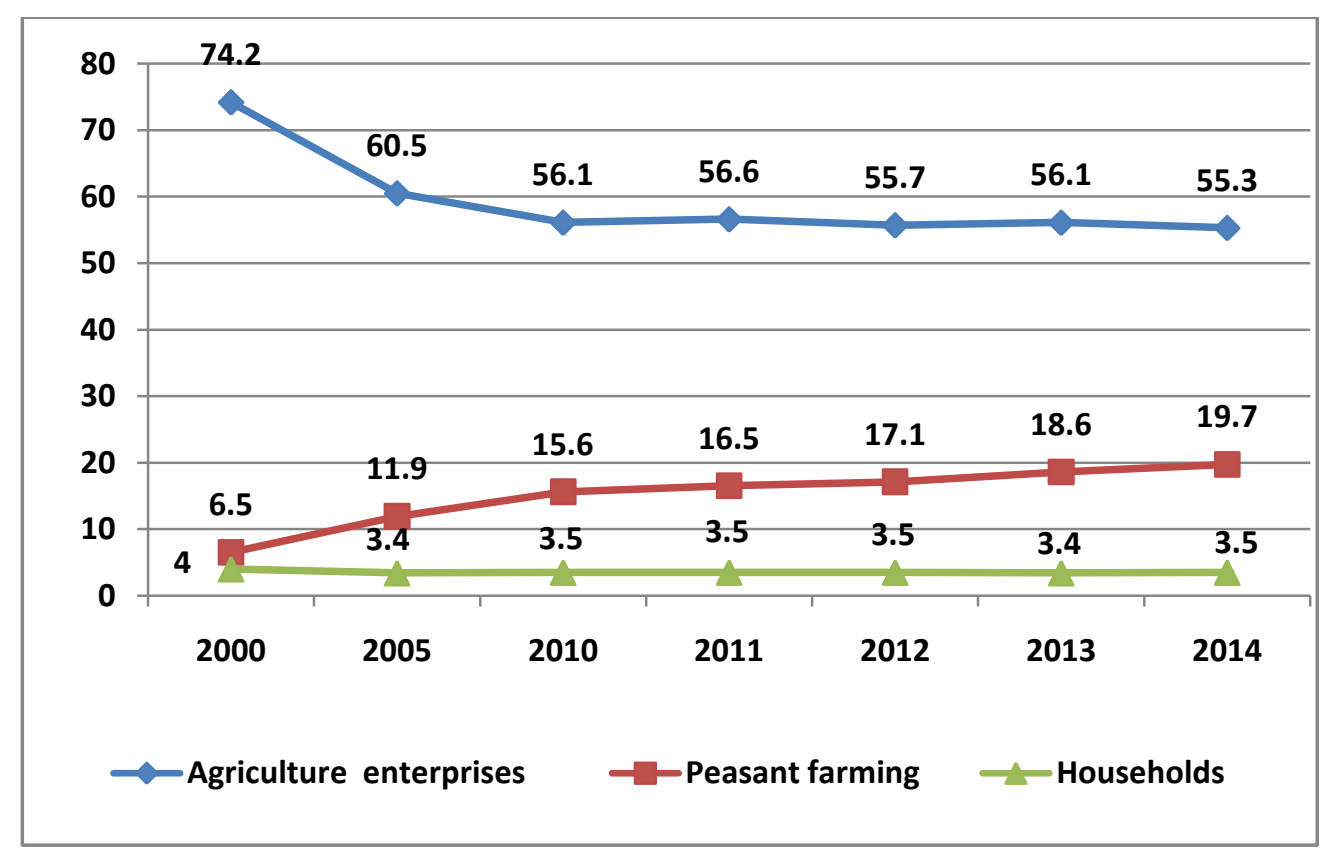

\section{FIGURE 5. DYNAMICS OF CULTIVATED AREAS BY CATEGORIES OF FARMS, mln ha Source: $[18$, p. 78$]$.}

At the end of January 2016, compared with the corresponding date in 2015, the number of cattle in the agricultural organizations decreased by $0.9 \%$, cows - by $1.5 \%$. The number of sheep and goats increased by $0.5 \%$, pigs - by $13.1 \%$, poultry - by $4.6 \%$. The production of livestock and poultry for slaughter (in live weight) in agricultural organizations in January 2016, compared to January 2015 increased by 5.1\% (in January 2015 compared to January 2014 year - on-year by $9.4 \%)$, milk - by $2.6 \%(4.2 \%)$, eggs - by $3.8 \%$ (1.3\%) [18, p.90].

\section{SUMMARY}

In summary, we can state that as a result of market transformations in agrarian economy had developed two equivalent (for contribution to agricultural production) sectors: corporate business, represented by agricultural organizations, and individual and family business sector, represented by private farms and individual entrepreneurs (formal sector) and households plots (informal sector). In these sectors in the post-reform period there was a reorientation and specialization of production, has formed a reliable network of distribution and processing of manufactured products, has been found adequate forms of interaction with business partners and with government.

For the implementation of the state program of development of agriculture in 2016, it was planned to send 237 billion rubles. It is possible to ensure, according to experts, only the inertial scenario of development of the industry. To support new 
investment projects were expected to Finance about 47 billion rubles, which amounted to $20 \%$ of the proposed financing of agriculture in 2016, Real investment in agriculture in 2016 increased by $10 \%$ and the share of profitable farms was 87 [17].

However, experts of the RF Ministry of economic development make optimistic forecasts of APK. Agricultural production in Russia in the next four years, according to their estimates, could grow by $7.8 \%$. The main contribution to the growth of agricultural production will provide livestock. The dairy industry in four years will increase just $1.7 \%$, growing at 7 per cent. While physical volume of investments in the agricultural sector in 2018 will account for $99.4 \%$ of the figure in 2014 [20], which casts doubt on the optimistic forecasts of the Ministry.

Optimism can be associated only with inexhaustible energy and creativity of the Russian peasantry, with its amazing ability to adapt in the most incredible institutional conditions to make the impossible - possible!

\section{REFERENCES}

[1] Russia in figures. 2017, Rosstat, $2017-511$ p.

[2] Z. Kalugina, O. Fadeeva, S. Bratusenko. Socio-economic polarization of rural space in Russia // Region: Economics and sociology, 2015, №3 (87), pp. 123-145.

[3] T.G.Nefedova, J. Pallot. Unknown agriculture, or who needs a cow? - Novoe Izdatelstvo, 2006. - 320 p.

[4] O. Nechiporenko and others. The Peasants of modern Russia: life worlds and social practices / ed. by O. Nechiporenko; Institute of philosophy and law SB RAS.- Novosibirsk: Publishing house SB RAS, 2015.- 252 c.

[5] A. Nikulin. Enterprises and family in Russia: socio-cultural symbiosis // Where goes Russia? Transformation of social sphere and social policy / ed. by T. I. Zaslavskaya. - M.:. Matter, 1998, pp. 218-229.

[6] O. Fadeyeva. Rural communities and economic structures: from survival to development / edited by Z. Kalugina. - Novosibirsk: IEIE SB RAS, 2015. - 264 p.

[7] P. Veliky. Russian village. The processes of post-Soviet transformation, ed. by Yu. S. Voronov.- Saratov: Scientific book, 2012. - 340 p.

[8] Z. Kalugina. Market transformation of agrarian sector of Russia. Sociological discourse. - Novosibirsk: Publishing house of IEIE SB RAS, 2015. - 342 p.

[9] Zemfira Kalugina. The Russian vector of agrarian reform: Lambert Academic Publishing RU - 2016.- 463 p.

[10] Labour and employment in Russia. 2015: Stat. SB./ Rosstat. M., 2015. - 274 p.

[11] Federal law "On peasant (farmer) economy" (entered into force on 11.06.2003, as amended 01.03.2015) URL // http://www.vedomosti.ru/economics/news/2015/08/14/604930-fns-zaregistrirovala-v-rossii

[12] Z. Kalugina. Social boundaries development of peasant (farm), Izv. SB as USSR, 1991, vol. 3. - Ser. Region: Economics and sociology.

[13] URL // http://www.vedomosti.ru/economics/news/2015/08/14/604930-fns-zaregistrirovala-v-rossii

[14] A. Terentyeva. Farm USA in the early XXI century: state and development trends // U.S. and Canada: economy, politics, culture, $2015,12 \mathrm{~N}(552)$, c. 85-101.

[15] URL// http://ria.ru/infografika/20150603/1067942815.html

[16] V. Vinogradsky. Peasant world in the discourse of generational grief // Sociological research, 2015, N12, pp. 82-91.

[17] The state program of development of agriculture and regulation of markets of agricultural products, raw materials and food for $2013-$ 2020. Sub-program "Support of small forms of managing" // http://stavikc.ru/index.php?option=com_content\&view=article\&id=2849:2013-2020\&catid=47:2009-08-05-12-01-51\&Itemid=66

[18] Agriculture, hunting and hunting economy, forestry in Russia. 2015: Stat. SB./ Rosstat. - M., 2015, 201 pp.

[19] L. Zimina. Agriculture: what is the secret of success? // http://bujet.ru/article/177647.php

[20] URL // http://agroinfo.com/selskoe-xozyajstvo-rossii-v-2016-godu-budet-razvivatsya-inercionno-0311201505/

[21] Z. Kalugina. The paradoxes of agrarian reform in Russia: sociological analysis of transformation processes, Novosibirsk, $2001 .-196$ p.

[22] Z. Kalugina. Agrarian Actors in the Localities // Explaining Post-Soviet Patchworks. Volume 1. Actors and Sectors in Russia between Accommodation and Resistance to Globalization. Ashgate. Aldershot. Burlington USA. Singapore. Sydney, 2001: 310-330.

[23] Z. Kalugina. Private Farming in Russia: a Thorny Path to Revival // Farming and Rural Systems Research and Extension. Local Identities and Globalisation. IFSA European Group, Florence, Italy, 2002: 148-157.

[24] Z. Kalugina. Adaptation Strategies of Agricultural Enterprises during Transformation // D. J.O'Brien and S.K.Wegren (ed.) Rural Reform in Post-Soviet Russia. Woodrow Wilson Center Press, Washington, D.C. USA, 2002: 367-384.

[25] Transformation and Diversification of Rural Societies in Eastern Europe and Russia. Ieda Osamu (ed.) Slavic Research Center, Hokkaido University, Sapporo, Japan, 2002: - 345 p.

[26] Z. Kalugina. Rural labor market in present Russia // Eastern European Countryside, 2005, №11, pp. 19-38.

[27] J.R. Franks, O. Fadeeva, I. Davydova, Z. Kalugina. Farm ownership and Management in Russia: A study of the Novosibirsk Region // Journal of Farm Management, Volume 12 No.6 October 2005, pp.329-350.

[28] Z. Kalugina. Institutional Traps in the Agrarian Transformation in Russia // Eastern European Countryside, 2007, №13, pp. 69-82.

[29] Russian Views of the Transition in the Rural Sector. Structures, Policy Outcomes, and Adaptive Responses / L. Alexander Norsworthy (ed.). The International Bank for Reconstruction and Development / The World Bank, Washington, D.C. USA, 2000, - 209 p. 